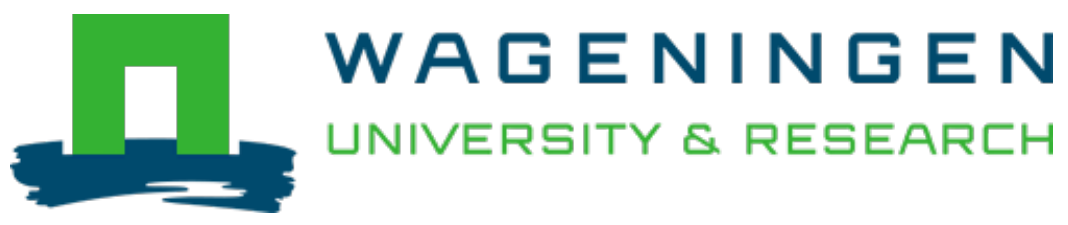

\title{
Increasing Temperature Counteracts the Negative Effect of UV Radiation on Growth and Photosynthetic Efficiency of Microcystis aeruginosa and Raphidiopsis raciborskii
}

Photochemistry and Photobiology

Noyma, Natália Pessoa; Mesquita, Marcella C.B.; Roland, Fábio; Marinho, Marcelo Manzi; Huszar, Vera L.M. et al

https://doi.org/10.1111/php.13377

This article is made publicly available in the institutional repository of Wageningen University and Research, under the terms of article $25 \mathrm{fa}$ of the Dutch Copyright Act, also known as the Amendment Taverne. This has been done with explicit consent by the author.

Article $25 \mathrm{fa}$ states that the author of a short scientific work funded either wholly or partially by Dutch public funds is entitled to make that work publicly available for no consideration following a reasonable period of time after the work was first published, provided that clear reference is made to the source of the first publication of the work.

This publication is distributed under The Association of Universities in the Netherlands (VSNU) 'Article $25 \mathrm{fa}$ implementation' project. In this project research outputs of researchers employed by Dutch Universities that comply with the legal requirements of Article $25 \mathrm{fa}$ of the Dutch Copyright Act are distributed online and free of cost or other barriers in institutional repositories. Research outputs are distributed six months after their first online publication in the original published version and with proper attribution to the source of the original publication.

You are permitted to download and use the publication for personal purposes. All rights remain with the author(s) and / or copyright owner(s) of this work. Any use of the publication or parts of it other than authorised under article $25 \mathrm{fa}$ of the Dutch Copyright act is prohibited. Wageningen University \& Research and the author(s) of this publication shall not be held responsible or liable for any damages resulting from your (re)use of this publication.

For questions regarding the public availability of this article please contact openscience.library@wur.nl 


\title{
Research Article
}

\author{
Increasing Temperature Counteracts the Negative Effect of UV Radiation \\ on Growth and Photosynthetic Efficiency of Microcystis aeruginosa and \\ Raphidiopsis raciborskii \\ Natália Pessoa Noyma ${ }^{1+*}$ (D), Marcella C.B. Mesquita ${ }^{1 \dagger}$ (D), Fábio Roland ${ }^{2}$ (D), Marcelo Manzi Marinho ${ }^{1}$ (D), \\ Vera L.M. Huszar ${ }^{3}$ (D) and Miquel Lürling ${ }^{4}$ (D) \\ ${ }^{1}$ Laboratory of Ecology and Physiology of Phytoplankton, Department of Plant Biology, University of Rio de Janeiro State, \\ Rio de Janeiro, RJ, Brazil \\ ${ }^{2}$ Laboratory of Aquatic Ecology, Department of Biology, Federal University of Juiz de Fora, Juiz de Fora, MG, Brazil \\ ${ }^{3}$ Museu Nacional, Federal University of Rio de Janeiro, Rio de Janeiro, RJ, Brazil \\ ${ }^{4}$ Aquatic Ecology \& Water Quality Management Group, Department of Environmental Sciences, Wageningen University, \\ Wageningen, The Netherlands
}

Received 8 July 2020, accepted 29 December 2020, DOI: 10.1111/php.13377

\begin{abstract}
High temperature can promote cyanobacterial blooms, whereas ultraviolet radiation (UVR) can potentially depress cyanobacterial growth by damaging their photosynthetic apparatus. Although the damaging effect of UVR has been well documented, reports on the interactive effects of UV radiation exposure and warming on cyanobacteria remain scarce. To better understand the combined effects of temperature and UVR on cyanobacteria, two strains of nuisance species, Microcystis aeruginosa (MIRF) and Raphidiopsis raciborskii (formerly Cylindrospermopsis raciborskii, CYRF), were grown at $24^{\circ} \mathrm{C}$ and $28^{\circ} \mathrm{C}$ and were daily exposed to UVA + UVB (PAR + UVA+UVB) or only UVA (PAR + UVA) radiation. MIRF and CYRF growth rates were most affected by PAR + UVA+UVB treatment and to a lesser extent by the PAR + UVA treatment. Negative UVR effects on growth, Photosystem II (PSII) efficiency and photosynthesis were pronounced at $24^{\circ} \mathrm{C}$ when compared to that at $28^{\circ} \mathrm{C}$. Our results showed a cumulative negative effect on PSII efficiency in MIRF, but not in CYRF. Hence, although higher temperature ameliorates UVR damage, interspecific differences may lead to deviating impacts on different species, and combined elevated temperature and UVR stress could influence species competition.
\end{abstract}

\section{INTRODUCTION}

Ultraviolet radiation (UVR) accounts for only nine percent of the total solar radiation that reaches the surface of the Earth and this energetic waveband can cause harmful effects on both terrestrial and aquatic organisms (1-3).

UVR, especially short wavelengths of UVB (280-315 nm), may affect several physiological processes of phytoplankton, such as photosynthesis, pigment production, growth, survival and

*Corresponding author email: np.noyma@gmail.com (Natalia Pessoa Noyma)

$\dagger$ These authors have contributed equally to this work.

(C) 2021 American Society for Photobiology
DNA integrity (4-8). Although the lesser energetic UVR wavelengths in UVA (315-400 nm) can be used as a source of energy for photosynthesis (9), at high levels, UVA can induce indirect damage to DNA and cause photoinhibition $(5,10,11)$.

Between 1979 and 1989, a drastic increase in solar UVR, mainly UVB, reaching the surface of the Earth, as a consequence of the reduction of the ozone layer caused by emissions of ozone-depleting substances (ODSs) due to anthropogenic activities, was reported (12). Despite international efforts to phase out ODSs under the Montreal Protocol, recent work revealed an increased emission of one of the ODS (trichlorofluoromethane, CFC-11) from eastern Asia since 2012 (13), which can delay the recovery of pre-1980 ozone layer levels. These chlorofluorocarbons (CFCs) are also potent greenhouse gases and their presence may further contribute to global warming (14).

Atmospheric warming is one of the most prominent symptoms of global climate change $(15,16)$ which is in turn known to affect both the structure and function of aquatic ecosystems $(17,18)$ and promote cyanobacterial blooms $(19,20)$. In addition, an elevated water temperature will directly affect the metabolic rates of the aquatic organisms (21). The well-known positive relationship between temperature and phytoplankton growth differs between species (22), and warming may promote the growth of species that have a higher optimal growth temperature (cyanobacteria), over those that have a lower optimal growth temperature, such as diatoms (19). Also, higher water temperatures could indirectly reduce the surface mixed layer depth (in extent and strength of stratification) exposing the photosynthetic organisms (including cyanobacteria) to higher intensities of solar radiation and, consequently, to UVR $(23,24)$.

Cyanobacteria are considered to be tolerant to UVR, as cyanobacteria evolved when the ozone layer was still developing (25). This generalization can, however, be questioned, because of the long evolutionary history current-day cyanobacteria surely do not need to share all traits with ancestorial ones. In fact, the sensitivity to UVR varies among cyanobacterial species; some species, or even some strains within a species, might be less tolerant to UVR exposure than others (26-28). Changes in 
physiological and morphological traits, for instance, photosynthetic rates, growth rates and size of the cells or trichomes can be observed (29-31). In general, cyanobacteria avoid or minimize the damage caused by UVR exposure using a range of mechanisms, including vertical migration (32), synthesis of protective UV-screening compounds (6), and production of enzymes that are capable of repairing damage (33).

Raphidiopsis raciborskii (formerly Cylindrospermopsis raciborskii) and Microcystis aeruginosa are two of the most frequent bloom-forming potentially toxic cyanobacteria worldwide $(34,35)$. $R$. raciborskii is often described as a low-light-adapted species $(36,37)$, however, recent studies have demonstrated its capacity to grow in a wide range of light intensities $(38,39)$. Conversely, M. aeruginosa has been considered as a species adapted to high light intensities (40-42). Although adaptation to different light conditions has been well documented for both species, previous experiments have mostly been conducted using solely photosynthetically active radiation (PAR), and the potential influence of UVR on their physiological responses has largely been neglected.

Studies on the interactive effects of UV radiation exposure and warming on cyanobacteria are still scarce $(26,27,43,44)$, especially for tropical strains (45). Increased temperature has been reported to counteract the damaging effect of UVR exposure on growth (44), photosynthesis $(26,27,43)$ and DNA breakage (45), although the outcome can be species dependent (43).

In this study, we examined the role of temperature and UVR on the growth rates and photosynthesis of two tropical cyanobacterial strains: $M$. aeruginosa (MIRF) and $R$. raciborskii (CYRF). Considering that these species differ in their adaptation to light we hypothesized that: (i) $M$. aeruginosa, as a species adapted to high light intensities, experiences less damage when compared to $R$. raciborskii upon UVR exposure; and (ii) elevated temperature counteracts the detrimental effect of UVR in both species.

\section{MATERIALS AND METHODS}

Cyanobacterial strains. The strains Raphidiopsis raciborskii (Woloszynska) Aguilera, Berrendero Gómez, Kastovsky, Echenique \& Salerno (LETC CYRF01 - CYRF) and Microcystis aeruginosa (Kützing) Kützing (LETC MIRF01 - MIRF) were obtained from the culture collection of the Laboratory of Ecophysiology and Toxicology of Cyanobacteria (LETC), Federal University of Rio de Janeiro (Brazil). Although the toxins were not measured in our study, previous analysis has revealed that this $R$. raciborskii strain produces saxitoxins and gonyautoxins (46), whereas the M. aeruginosa strain produces a variety of microcystins (47). MIRF grew as single cells in the laboratory cultures, and not as colonies, as observed commonly in the field (48).

Culture conditions. CYRF and MIRF stock cultures were maintained in $250-\mathrm{mL}$ Erlenmeyer flasks containing $100 \mathrm{~mL}$ modified $\mathrm{WC}$ medium (49), at $24^{\circ} \mathrm{C}$ in $90 \mu \mathrm{mol}$ photons $\mathrm{m}^{-2} \mathrm{~s}^{-1}$ provided in a $12: 12 \mathrm{~h}$ light-dark cycle in a temperature and light-controlled incubator (Sanyo, MLR-351H). Prior to the experiment, the organisms were acclimatized to the experimental temperature conditions for three days. Each culture was transferred to a $300-\mathrm{mL}$ quartz Erlenmeyer flasks containing $100 \mathrm{~mL}$ of WC medium. The initial culture concentration was $20 \mu \mathrm{g}$ chlorophyll- $a$ $\mathrm{L}^{-1}$ (detailed methods described in the subsection "Effects of UVR on growth rate and photosynthetic efficiency"). The flasks were shaken manually twice every day.

Light conditions. To evaluate the effects of different UV wavebands on the growth and photosynthetic efficiency, three light treatments were performed: PAR $(400-700 \mathrm{~nm})$, PAR + UVA $(315-700 \mathrm{~nm})$ and PAR + UVA+UVB $(280-700 \mathrm{~nm})$. The PAR treatment was provided using a fluorescent tube T8 Luxline Plus F30W/T8/865 (Sylvania, Germany). A filter was not placed on the tube because their UV emissions were considered negligible based on the manufacturer's information. Cultures were exposed to artificial UVR supplied by UVA and UVB lamps (TL-K 40W UVA 1SL, Philips and VL-115M, Vilber Lourmat, respectively). The UVC radiation emitted by the UV lamps was screened out by covering the lamps with cellulose acetate foil. To avoid changes on the absorbance properties, the cellulose acetate foil was replaced every second day.

The light intensity inside the quartz Erlenmeyer flasks was measured using a fiber-optic spectrometer (AvaSpec 2048, Avantes, The Netherlands). The experimental light intensities that were used included $0.5 \mathrm{~W} \mathrm{~m}^{-2}$ (UVB), $10 \mathrm{~W} \mathrm{~m}^{-2}$ (UVA) and $90 \mu \mathrm{mol}$ photon $\mathrm{m}^{-2} \mathrm{~s}^{-1}$ (PAR). The UVR intensities were applied based on previous work (50), and correspond to the natural solar radiation measurements recorded in southeastern Brazil. In the PAR + UVA treatment, the flasks were wrapped with Mylar foil, which blocked wavelengths below $320 \mathrm{~nm}$ (51). The UVA and UVB lamps were switched on for $4 \mathrm{~h}$ per day in the middle of a 12:12 h light-dark cycle. The bottles were shaken manually twice every day, and their position inside the incubator was randomly changed, to ensure equal light conditions.

Experiments were conducted in triplicates for each experimental temperature $\left(24\right.$ and $\left.28^{\circ} \mathrm{C}\right)$ using the two strains of cyanobacteria (MIRF and CYRF) for five days. The tested temperatures were based on the annual mean of the reservoir from where the strains were isolated (52) and the $4^{\circ} \mathrm{C}$ increase projected for South America by the end of the twenty-first century (53)

Effects of UVR on growth rate and photosynthetic efficiency. Chlorophyll- $a$ concentrations (Chl- $a, \mu \mathrm{g} \mathrm{L} \mathrm{L}^{-1}$ ) and photosystem II efficiency (PSII efficiency) of MIRF and CYRF strains were measured before and after $4 \mathrm{~h}$ of daily UV exposure using a Phyto-PAM phytoplankton analyzer (Heinz Walz GmbH, Effeltrich, Germany). The PSII efficiency of the light-adapted cells corresponded to the effective quantum yield and was measured using a saturating pulse $(0.2 \mathrm{~s})$ provided by actinic illumination employing red LED lights (emission peak $655 \mathrm{~nm}$; intensity $2600 \mu \mathrm{mol}$ photon $\mathrm{m}^{-2} \mathrm{~s}^{-1}$ ).

Samples for biovolume estimation $\left(\mu \mathrm{m}^{3} \mathrm{~mL}^{-1}\right)$, mean particle volume $(\mu \mathrm{m})$ and particles concentration (particles $\mathrm{mL}^{-1}$ ) were collected daily, after the UV exposure and measured in triplicate using an automated cell counter (Casy Cell Counter, Schaerfe System GmbH, Reutlingen, Germany) with a $120 \mu \mathrm{m}$ capillary.

As a reduction of pigment content is expected by the UVR treatments in phytoplanktonic organisms (54), we estimated the growth rates based on Chl- $a$ concentrations, particles- and biovolume concentrations. Growth rates $\left(\mu, \mathrm{d}^{-1}\right)$ of each treatment were estimated using the equation $\mu=\ln$ $\left[N_{\mathrm{t}} / N_{0}\right] / t$; where $\mu$ represents the growth rate, $N_{0}$ and $N_{\mathrm{t}}$ represent initial and final Chl- $a$ concentration, particles or biovolume, and $t$ represents the duration of incubation in days $(t=5)(55)$.

Rapid light curves and curve fitting. The effects of the UVR on the photosynthesis capacity were assessed by rapid light curves (RLC) using Phyto-PAM and the data was recorded using the PhytoWin software. Samples were collected after the UVR exposure at days 1 and 5 and were exposured to 10 incremental light intensities ranging from 0 to $2064 \mu \mathrm{mol}$ photon $\mathrm{m}^{-2} \mathrm{~s}^{-1}$ for $20 \mathrm{~s}$.

RLCs measure the relative electron transport rate (rETR) as a function of irradiance. The rETR was calculated using the follow equation: $\mathrm{rETR}=$ PSII efficiency $\times$ PAR .

The RLCs were fitted to a double exponential decay function (56), using a Marquardt-Levenberg regression algorithm, as proposed by Ralph and Gademann (2005) (57):

$$
P=\operatorname{Ps}\left(1-e^{-(\alpha E d / \mathrm{Ps})}\right) e^{-(\beta \mathrm{Ed} / \mathrm{Ps})}
$$

In the absence of photoinhibition $(\beta=0)$, the function can be simplified (58) to:

$$
P=\mathrm{ETR}_{\max }\left(1-e^{-(\alpha \mathrm{Ed} / \mathrm{ETR} \max )}\right)
$$

where $\mathrm{Ps}$ is a scaling factor representing the maximum potential rETR, rETR $_{\max }$ is the maximum rETR under saturating irradiance, alpha $(\alpha)$ is the initial slope of the curve (represents the maximum quantum yield of PSII, (59)), Ed represents the downwelling irradiance $(400-700 \mathrm{~nm})$, and beta $(\beta)$ characterizes the slope of the RLC where rETR declines (60). The $\mathrm{rETR}_{\max }$ and $\mathrm{E}_{\mathrm{k}}$ (light saturation parameter) were estimated as follows: 


$$
\begin{gathered}
r \mathrm{ETR}_{\max }=P_{s}(\alpha /[\alpha+\beta])(\beta /[\alpha+\beta])^{\beta / \alpha} \\
E_{k}=r \mathrm{ETR}_{\text {max }} / \alpha
\end{gathered}
$$

Statistics and calculation. The response ratio (RRx) was calculated using growth rates based on Chl- $a$ (RR-Chl- $a$ ) and biovolume (RRbiovol) as an effect size index, to verify the harmful effect of the $\mathrm{PAR}+\mathrm{UVA}+\mathrm{UVB}$ and PAR + UVA treatments on the growth rate normalized by the PAR treatment (considered the control), as follows: $\mathrm{RR}=\ln$ (growth rate treatment) - $\ln$ (growth rate control). RRs are commonly used as an effect size metric in phytoplankton research $(61,62)$.

To verify the effects of light treatments and temperature on the growth rates of $M$. aeruginosa and $R$. raciborskii, a three-way analysis of variance (ANOVA), with light treatments, temperature and strains as fixed factors was conducted. Data normality and heteroscedasticity were tested using the Normality Test (Shapiro-Wilk) and equal variance test in SigmaPlot prior to running the ANOVA. Pairwise multiple comparison procedures (Holm-Sidak method) were applied to distinguish means that were significantly different $(P<0.05)$. All statistical analyses were performed using the tool pack SigmaPlot ${ }^{\circledR}$ version 12.5.

To estimate the cumulative damage on PSII caused by UVR, PSII values were recorded daily, before the UVR exposure, were plotted against time. Subsequently, the slopes were statistically compared by a parallel line analysis using SigmaPlot (version 12.5).

Curve fitting was performed using the statistical software R (RCore Team, 2013), using the "phytotools" package (63). The RLCs were quantitatively compared using $\alpha, \mathrm{E}_{\mathrm{k}}$, rETR $\mathrm{rax}_{\max }$ and $\beta$ parameters. For the experiment set at $24^{\circ} \mathrm{C}$, means of PAR and PAR + UVA for both strains were compared using Student's $t$-test or nonparametric Mann-Whitney $U$-test with the level of significance set at $P<0.05$. For $28^{\circ} \mathrm{C}$, a twoway ANOVA was run and pairwise multiple comparison procedures (Holm-Sidak method) were applied to distinguish means that were significantly different $(P<0.05)$. The statistics were performed in the tool pack SigmaPlot $^{\circledR}$ version 12.5.

\section{RESULTS}

\section{Effects of UVR on growth rates}

The Chl- $a$ based growth rates of MIRF and CYRF were affected by the light treatment and temperature (Fig. 1 and Figure S1). Three-way ANOVA indicated statistically significant differences between the strains, light treatments and temperature, and statistically significant interactions between strains $\times$ light treatments, strains $\times$ temperature and light treatments $\times$ temperature (Table 1). The lowest growth rates were observed in the PAR + UVA+UVB treatment at $24^{\circ} \mathrm{C}$ for MIRF $\left(0.13 \pm 0.03 \mathrm{~d}^{-1}\right)$ and CYRF $\left(0.14 \pm 0.04 \mathrm{~d}^{-1}\right)$ and the highest values were found in controls (PAR only) at $28^{\circ} \mathrm{C}$ for MIRF $\left(0.59 \pm 0.02 \mathrm{~d}^{-1}\right)$ and CYRF $\left(0.63 \pm 0.03 \mathrm{~d}^{-1}\right)$. Regardless of the light condition, growth rates of the two strains were higher at $28^{\circ} \mathrm{C}$ than at $24^{\circ} \mathrm{C}$ $(P<0.001)$. There was no significant difference between MIRF and CYRF in the PAR + UVA+UVB treatments at $24^{\circ} \mathrm{C}$ and 28 ${ }^{\circ} \mathrm{C}$.

In general, the particles number-based (Figures S3 and S4) and biovolume-based growth rates were similar to Chl- $a$-based growth (Fig. 1B and Figure S2). Three-way ANOVA indicated statistically significant differences between strains, light treatments and temperature, as well as statistically significant interactions between strains $\times$ light treatments, strains $\times$ temperature, light treatments $\times$ temperature and strains $\times$ light treatments $\times$ temperature (Table 1 ). The strain $\times$ temperature interaction effect depended on the light condition applied. In the $\mathrm{PAR}+\mathrm{UVA}+\mathrm{UVB}$ treatment, MIRF growth rates were significantly lower than that of CYRF at $24{ }^{\circ} \mathrm{C}(P<0.001)$ and $28^{\circ} \mathrm{C}$ $(P=0.028)$, however, in the PAR + UVA and PAR treatments, no statistically significant differences were observed between the strains $(P=0.307$ and $P=0.381$, respectively). Both strains expressed significantly higher growth rates in the PAR $(P=0.005)$ and PAR + UVA $(P<0.001)$ treatments at $28^{\circ} \mathrm{C}$ than at $24^{\circ} \mathrm{C}$.

Response ratios (RR) verified the magnitude of the effect of UVR on growth. The calculated ratios yielded negative values, indicating a negative effect of the treatments (PAR + UVA+UVB and PAR + UVA). RR-Chl- $a$ showed more negative values in MIRF and CYRF in the PAR + UVA+UVB treatments at $24^{\circ} \mathrm{C}$ than at $28^{\circ} \mathrm{C}$ (Fig. $1 \mathrm{C}$ ). At $28^{\circ} \mathrm{C}$, the damaging effect of PAR + UVA+UVB appeared to be $50 \%$ less in MIRF and $80 \%$ less in CYRF compared to $24^{\circ} \mathrm{C}$. The RR-Chl- $a$ in the PAR + UVA treatment in MIRF were similar at $24^{\circ} \mathrm{C}(-0.179)$ and $28^{\circ} \mathrm{C}(-0.156)$; however, in CYRF, the damaging effect was $52 \%$ less at $28^{\circ} \mathrm{C}$ than at $24^{\circ} \mathrm{C}$. RR-biovol showed a similar pattern as RR-Chl- $a$ (Fig. 1D), although several RR-biovol values were more negative than the corresponding RR-Chl- $a$ (Fig. 1C, D). MIRF at $24^{\circ} \mathrm{C}$ revealed RR-biovol values to be -3.022 in the PAR + UVA+UVB treatment and -0.295 in the PAR + UVA treatment. At $28^{\circ} \mathrm{C}$, the strong negative effect of the $\mathrm{PAR}+\mathrm{UVA}+\mathrm{UVB}$ treatment in MIRF was reduced by $73 \%$, while no expressive difference was observed in the PAR + UVA treatment (Fig. 1D). In CYRF, the higher temperature diminished the negative effect by $90 \%$ (PAR + UVA+UVB) and by $88 \%$ $(\mathrm{PAR}+\mathrm{UVA})$.

\section{Effect of UVR on photosynthetic efficiency}

The short-term effect of the UVR treatments on PSII efficiency was monitored daily, before and after the exposure period. In the PAR treatment (without any UVR addition), the PSII values before and after $4 \mathrm{~h}$ incubation did not differ for both species and at both temperatures throughout the experiment (Fig. 2). In contrast, when exposed to the treatments with UVR addition at $24^{\circ} \mathrm{C}$ for $4 \mathrm{~h}$, a strong reduction in the PSII efficiencies was observed in both strains. In the PAR + UVA+UVB treatments PSII efficiency in MIRF was reduced by $98 \%$ while in CYRF it was reduced by $97 \%$. In the PAR + UVA treatment the reduction in PSII efficiency was $68 \%$ in MIRF and $74 \%$ in CYRF. MIRF showed a daily return to the initial PSII efficiency in the PAR + UVA treatment, but not in the PAR + UVA+UVB treatment in which a gradual decline was observed (Fig. 2). PSII efficiency in CYRF exposed to UVR at $24^{\circ} \mathrm{C}$ recovered to the initial values after each exposure, irrespective of the treatment. A similar behavior was observed in CYRF exposed to UVR at $28^{\circ} \mathrm{C}$; PAR + UVA caused a $28 \%$ reduction in PSII efficiency and, PAR + UVA+UVB caused a $66 \%$ reduction, however, in both treatments daily recovery occurred (Fig. 2). When MIRF was cultured at $28^{\circ} \mathrm{C}$, PSII efficiencies declined in both the PAR + UVA (39\%) and PAR + UVA+UVB (86\%) treatments, however, a completed daily recovery was only observed in the PAR + UVA exposure (Fig. 2).

The cumulative damaging effect of UVR exposure on the PSII was inferred from PSII efficiency values recorded before the period of exposure (Fig. 3). Parallel lines analysis revealed that the slopes of the PSII efficiencies of each light treatment against the time (days) were different in MIRF at $24^{\circ} \mathrm{C}\left(F_{2,39}=38.21\right.$, $P<0.001)$ and $28^{\circ} \mathrm{C}\left(F_{2,39}=71.74, P<0.001\right)$. At $24^{\circ} \mathrm{C}$, the slope in the PAR + UVA+UVB treatment was lower than in PAR + UVA $(-0.106$ and -0.034 , respectively), whereas at 


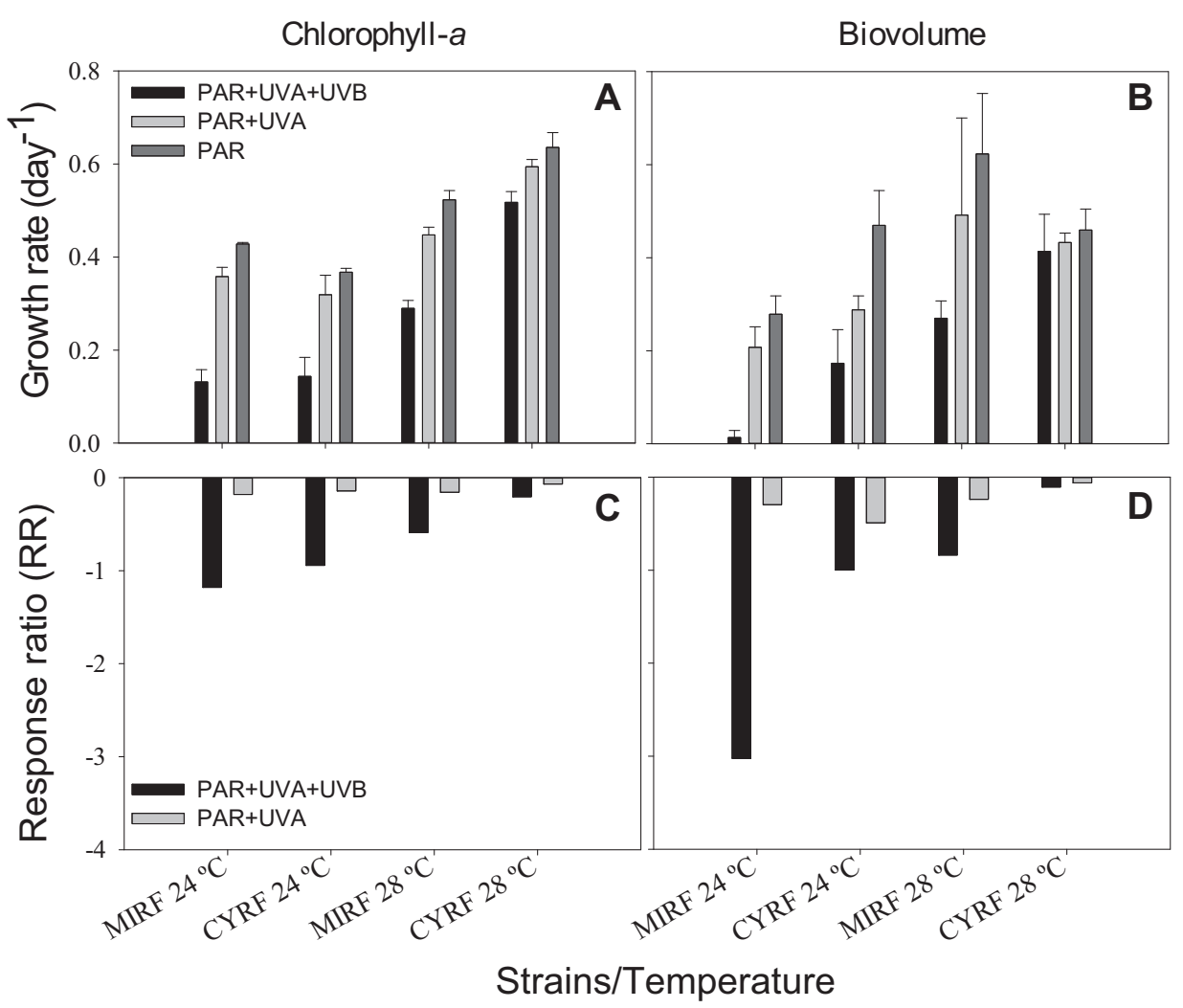

Figure 1. Growth rates of Raphidiopsis raciborskii (CYRF) and Microcystis aeruginosa (MIRF) based on chlorophyll-a (A) and biovolume (B) and response ratio of the treatments based on chlorophyll-a concentration (C) and biovolume (D), at $24^{\circ} \mathrm{C}$ and $28^{\circ} \mathrm{C}$. PAR $=$ photosynthetically active radiation. Error bars indicate one standard deviation $(n=3)$.

Table 1. Summary of three-way ANOVA of growth rate of the two strains (Microcystis aerugionosa and Cylindrospermopsis raciborskii) exposed to three different light treatments and two temperatures.

\begin{tabular}{lcc}
\hline & \multicolumn{2}{c}{ Growth rate } \\
\cline { 2 - 3 } Source of variation & Chl- $a$ & Biovolume \\
\hline Strain & $F_{1,35}=65.46 ;$ & $F_{1,35}=42.90 ;$ \\
& $P<0.001$ & $P<0 ., 001$ \\
Light treatment & $F_{2,35}=249.98 ;$ & $F_{2,35}=80.26 ;$ \\
& $P<0.001$ & $P<0.001$ \\
Temperature & $F_{1,35}=649.90 ;$ & $F_{1,35}=147.17 ;$ \\
& $P<0 ., 001$ & $P<0.001$ \\
Strain $\times$ light treatment & $F_{2,35}=11.44 ;$ & $F_{2,35}=23.14 ;$ \\
& $P<0.001$ & $P<0.001$ \\
Strain $\times$ temperature & $F_{1,35}=135.46 ;$ & $F_{1,35}=39.81 ;$ \\
& $P<0.001$ & $P<0.001$ \\
Light & $F_{2,45}=11.67 ;$ & $F_{2,45}=28.81 ;$ \\
treatment $\times$ temperature & $P<0.001$ & $P<0.001$ \\
Strain $\times$ light & $F_{20,35}=0.58 ;$ & $F_{20,35}=5.33 ;$ \\
treatment $\times$ temperature & $P=0.563$ & $P=0.012$ \\
& & \\
\hline
\end{tabular}

$28^{\circ} \mathrm{C}$, the slopes in the PAR + UVA+UVB $(-0.065)$ and PAR + UVA $(-0.001)$ treatment were higher than at $24^{\circ} \mathrm{C}$. In CYRF, the slopes differed among the light treatments at $24^{\circ} \mathrm{C}$ $\left(F_{2,39}=5.87, P=0.005\right)$, the slope in the PAR + UVA+UVB treatment $(-0.007)$ was lower than in the PAR + UVA $(0.021)$ treatment. However, there was no significant difference at $28^{\circ} \mathrm{C}$ $\left(F_{2,39}=0.77, P=0.466\right)$, indicating a noncumulative effect (Fig. 3).

\section{Effect of UVR on rapid light curve parameters}

Exposure to UV radiation negatively affected the photosynthesis parameters (Fig. 4), especially in case of the PAR + UVA+UVB treatment. No statistically significant difference was observed between days 1 and 5 for all parameters tested (Mann-Whitney $U$-Test; $P>0.05$ ), therefore, only the results at day 5 were presented.

The photosynthetic parameters (alpha, $\mathrm{rETR}_{\max }, \mathrm{E}_{\mathrm{k}}$ ) were significantly higher at $28^{\circ} \mathrm{C}$ than at $24^{\circ} \mathrm{C}(P<0.05)$. At $24^{\circ} \mathrm{C}$, it was not possible to fit the RLCs for the PAR + UVA+UVB treatment due to the null values of PSII efficiency observed for both strains after $4 \mathrm{~h}$ of UV exposure. However, in MIRF, alpha $(P<0.01)$ and $\mathrm{rETR}_{\max }(P=0.05)$ in the PAR + UVA treatment were significantly lower than in the PAR control, while no differences were observed for beta and $\mathrm{E}_{\mathrm{k}}(P>0.05)$. In CYRF, all parameter values (alpha, $\mathrm{rETR}_{\max }, \mathrm{E}_{\mathrm{k}}$ ) were significantly lower in the PAR + UVA treatment than in PAR alone ( $t$-test $P<0.05)$.

At $28^{\circ} \mathrm{C}$, all photosynthetic parameters of MIRF and CYRF were affected by the light treatment and temperature (Fig. 4). For alpha values (Fig. 4A), a two-way ANOVA indicated statistically significant differences between the strains $\left(F_{1,12}=5.17\right.$, $P<0.05)$, light treatments $\left(F_{2,12}=175.64, P<0.001\right)$, and statistically significant interactions between strains $\mathrm{x}$ light treatments $\left(F_{2,12}=19.01, P<0.001\right)$. The lowest value observed was for MIRF in the PAR + UVA+UVB treatment $($ alpha $=$ $0.14 \pm 0.03)$. 


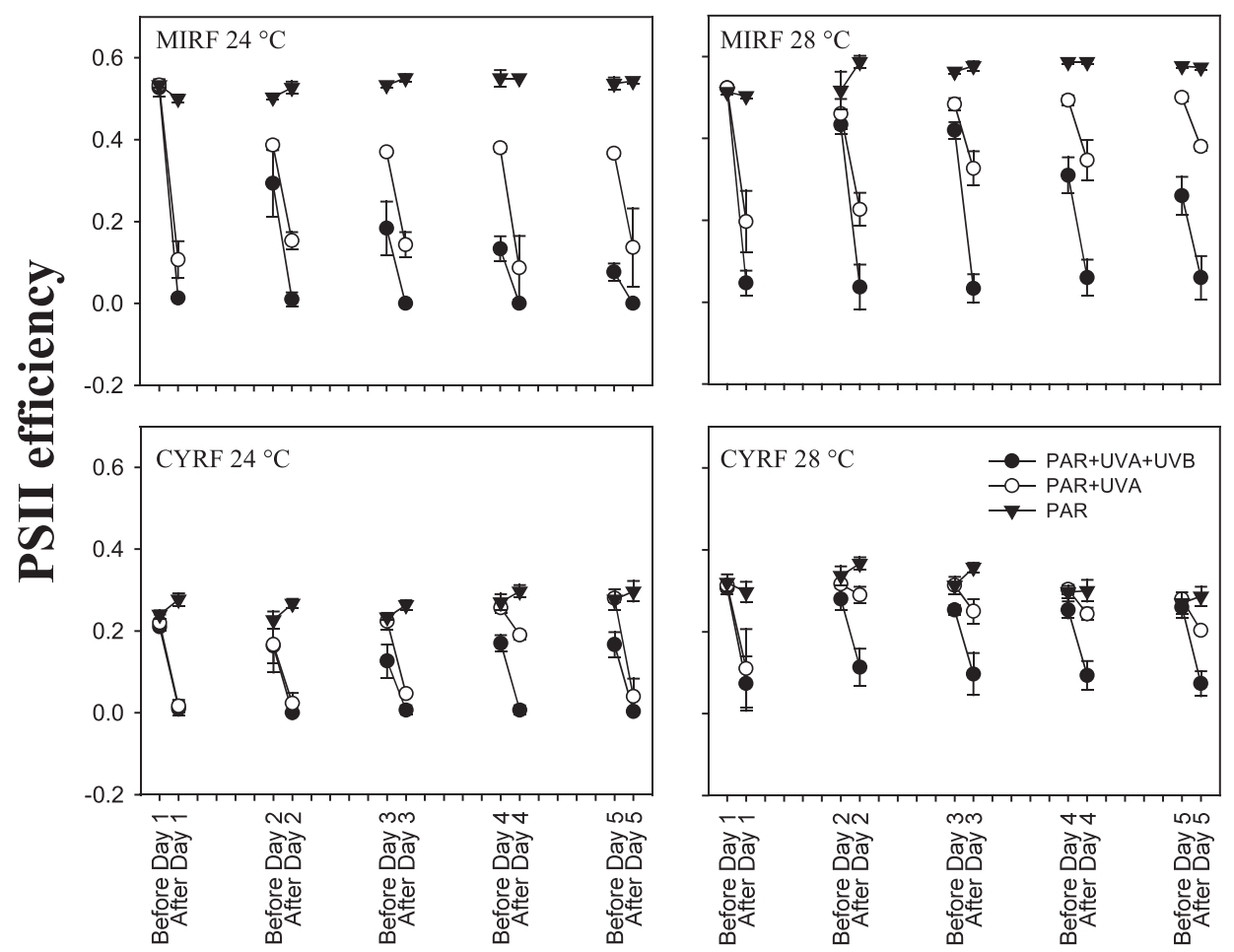

Sampling/Day

Figure 2. Daily efficiency of photosystem II (PSII) of Raphidiopsis raciborskii (CYRF) and Microcystis aeruginosa (MIRF) at $24^{\circ} \mathrm{C}$ and $28^{\circ} \mathrm{C}$, before and after ultraviolet radiation exposure each day for 5-day experiment. Symbols indicate mean values of the different radiation treatments: PAR + UVA+UVB, PAR + UVA and PAR (photosynthetically active radiation). Error bars indicate standard deviation $(n=3)$.

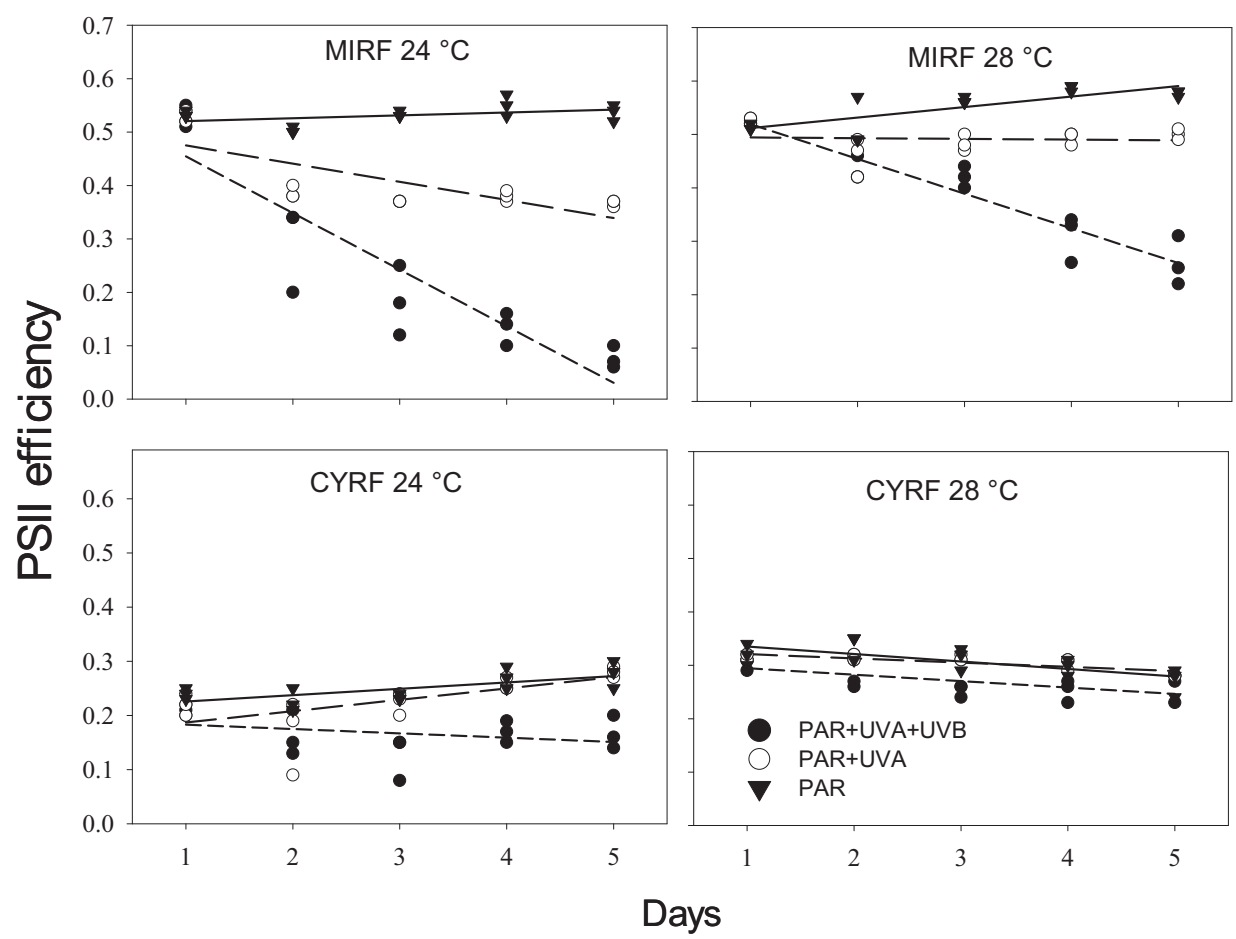

Figure 3. Parallel line analysis between PSII efficiency (efficiency of photosystem II) and time of the experiment (1-5 days), before ultraviolet radiation exposure measurements of Raphidiopsis raciborskii (CYRF) and Microcystis aeruginosa (MIRF) at $24^{\circ} \mathrm{C}$ and $28^{\circ} \mathrm{C}$. Symbols indicate values of the different radiation treatments: PAR + UVA+UVB , PAR + UVA and PAR (photosynthetically active radiation). 

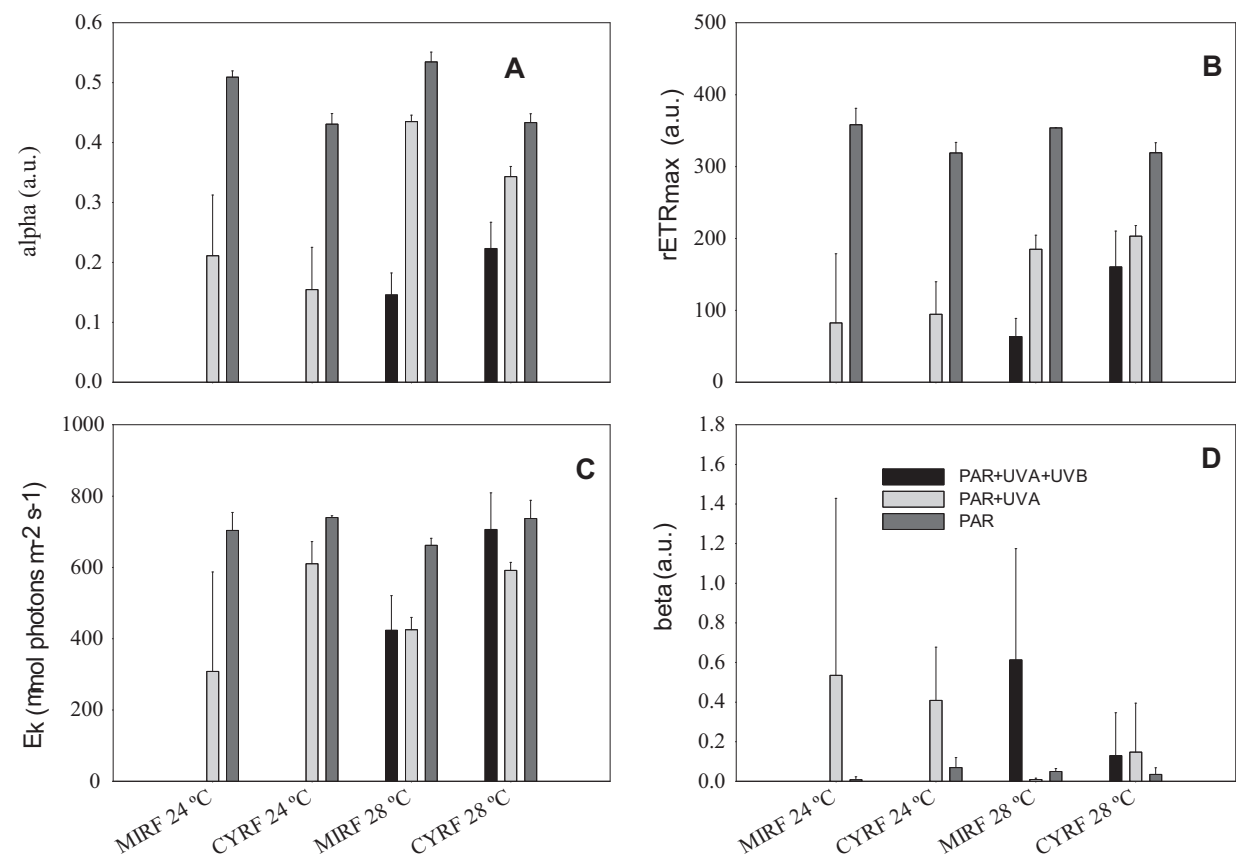

Strains/Temperature

Figure 4. Photosynthetic parameters of Raphidiopsis raciborskii (CYRF) and Microcystis aeruginosa (MIRF) at $24^{\circ} \mathrm{C}$ and $28^{\circ} \mathrm{C}$. (A) alpha, (B) relative electron transport rate $(\mathrm{rETR}),(\mathrm{C})$ light saturation parameter $\left(\mathrm{E}_{\mathrm{k}}\right)$ and $(\mathrm{D})$ beta, the slope of the rapid light curve where rETR declines. PAR $=$ photosynthetically active radiation. Error bars indicate one standard deviation $(n=3)$.

In both strains, rETR $_{\max }$ was strongly affected by the light treatment, especially in the PAR + UVA+UVB treatment (twoway ANOVA; $\left.F_{2,12}=39.29, P<0.001\right)$, where $\mathrm{rETR}_{\max }$ values in MIRF were statistically lower than in CYRF (Holm-Sidak post hoc test, $P<0.001)$. In MIRF, compared to the PAR control, FETR $_{\max }$ in the PAR + UVA+UVB and PAR + UVA treatment was $82 \%$ and $47 \%$ lower, respectively, whereas in CYRF $\mathrm{rETR}_{\text {max }}$ was $42 \%$ lower in the PAR + UVA+UVB treatment and $36 \%$ in the PAR + UVA treatment.

For $\mathrm{E}_{\mathrm{k}}$ values (Fig. 4C), two-way ANOVA indicated statistically significant differences between the strains $\left(F_{1,12}=29.39\right.$, $P<0.001)$, light treatments $\left(F_{2,12}=11.55, P=0.002\right)$, and statistically significant interactions between strains $\mathrm{x}$ light treatments $\left(F_{2,12}=4.13, \quad P<0.05\right)$. No statistically significant difference between the PAR + UVA+UVB and PAR + UVA treatments was observed in MIRF (Holm-Sidak post hoc test, $P>0.05)$, but both treatments differed from the PAR control $(P<0.002)$. In CYRF, there was no significant difference between the light treatments $(P>0.05)$.

No statistically significant differences were found in beta values between the strains $\left(F_{1,12}=0.64, P=0.43\right)$, light treatments $\left(F_{2,12}=2.54, P>0.05\right)$ and no statistically significant interactions between strains $\times$ light treatments were found $\left(F_{2,12}=1.99, P<0.05\right)$ (Fig. 4D).

\section{DISCUSSION}

In this study, the combined effect of UVR and temperature on the growth and PSII efficiency of two cyanobacterial species was evaluated. As expected, we observed a negative response to UVR exposure, especially UVB, in both species. However, the $M$. aeruginosa strain MIRF seemed to be more sensitive to UVR when compared to the $R$. raciborskii strain CYRF, refuting our first hypothesis.

Our results indicated a species-dependent response to UVR. Both growth rate and PSII efficiency were affected differently in CYRF and MIRF. Similar observations have been made in other studies, where significant to moderate effects on the growth rate were found, depending on the cyanobacterial species tested $(4,28,64,65)$. Furthermore, recent studies have reported intraspecies variability in UVB sensitivity (27-29). Beamud et al (2016) (28) investigated the stress induced by UVB radiation on the fitness of different cyanobacteria species, including one strain of $M$. aeruginosa and three different strains of $R$. raciborskii. The authors observed that $M$. aeruginosa was the least affected by UVB exposure, while the response varied between the three strains of $R$. raciborskii . In contrast, the current study found the opposite, a higher tolerance to UVR stress was observed in the $R$. raciborskii strain CYRF compared to the M. aeruginosa strain MIRF, which underpins the importance of studies that are conducted using different strains.

The growth rate was calculated using different variables (Chl$a$ and biovolume), which yielded similar outcomes. MIRF and CYRF showed no differences in Chl- $a$-based growth rate in the $\mathrm{PAR}+\mathrm{UVA}+\mathrm{UVB}$ or $\mathrm{PAR}+\mathrm{UVA}$ treatment at $24^{\circ} \mathrm{C}$, however, at $28^{\circ} \mathrm{C}, \mathrm{CYRF}$ growth rates were significantly higher than that of MIRF in all light conditions, indicating that the increase in temperature counterbalances the detrimental effects of the UVR addition in CYRF. Growth inhibition expressed by biovolume was more pronounced than when the growth was based solely on Chl- $a$ concentration. In another study, a $3 \mathrm{~h}$ daily exposure of $M$. aeruginosa to $1.05 \mathrm{~W} \mathrm{~m}^{-2} \mathrm{UVB}$ radiation resulted in a small decline in Chl- $a$ concentration whereas a significant reduction in the optical density $\left(\mathrm{OD}_{750}\right)$ was observed 
(65). Furthermore, short-term exposure $(6 \mathrm{~h})$ to moderate UVB and UVA radiation can directly damage cell structures by reducing the cytoplasmatic area occupied by thylakoids, disarranging phycobilisomes and polyphosphate granules in CYRF (50). The expressive reduction of biovolume-based growth rate, especially in MIRF at $24{ }^{\circ} \mathrm{C}$, can be attributed to the accentuated damage to subcellular structures caused by exposure to UVR. A decrease of the mean biovolume values of the cells (MIRF) and filaments (CYRF) observed in the UVR treatments during the experiment (Figure S5) could indicate deterioration of cell structures that limited the growth in these strains. Negative effect of UVR in cyanobacterial morphology has been reported in the literature $(28,43)$

MIRF was affected considerably by the PAR + UVA+UVB treatment at $24^{\circ} \mathrm{C}$, although growth suppression was also observed at $28^{\circ} \mathrm{C}$. Conversely, the negative effect of PAR + UVA+UVB treatment on CYRF was completely neutralized by the rise in temperature. Species-dependent effects of short wavelength UVR on growth rates were also observed in natural phytoplankton, in which growth inhibition occurred in chlorophytes, diatoms and picocyanobacteria, but not in larger filament or colony-forming cyanobacterial species such as Planktothrix sp. and Woronichinia sp. (66). This might be because the growth form of MIRF, mostly unicellular, influences its sensitivity to UVR. For instance, UVB exposure caused a lower growth inhibition in the colonial morphotype of a $M$. aeruginosa strain than in its single-celled form (67). Despite the fact that photosynthetic activities were inhibited in both phenotypes, the colonial morphotype had higher tolerance to UVB exposure, and a high recovery ability due to self-shading and protective effects of the mucous sheath (67).

To illustrate the response of each UV radiation treatment (PAR + UVA+UVB or PAR + UVA) on the growth rate of the two strains of cyanobacteria, we calculated the response ratio (RR) which is commonly used as a metric of experimental effect that quantifies the proportional change related to an experimental manipulation (68). Here, changes relative to the control, facilitate a better comparison than the absolute differences between the mean growth rates in each treatment (62). RRx for the PAR + UVA treatment showed similar values for both temperature and species. CYRF and MIRF showed a similar RRx in PAR + $\mathrm{UVA}+\mathrm{UVB}$ treatment at $24^{\circ} \mathrm{C}$; however, at $28^{\circ} \mathrm{C}$, CYRF presented lower RRx compared to MIRF. These measures confirm the observations on growth rate, reinforcing a benefiting outcome of the temperature interaction with UV exposure for CYRF.

The PSII complex is one of the main targets of UVR, mainly because of the impairment of the D1 protein, an essential component of PSII that binds the primary donors and acceptors active in PSII electron transport (3). Jiang and Qui (2011) (29) concluded that PSII in $M$. aeruginosa is more sensitive to higher UVB intensity $\left(3.15 \mathrm{~W} \mathrm{~m}^{-2}\right)$ than PSI, and the oxygen-evolving complex of PSII, which is involved in the photooxidation of water during the light reaction of photosynthesis, may be another inhibition site. In general, we observed a daily decline of the PSII efficiency after the UVR exposure in both MIRF and CYRF. The strongest reduction was observed in the PAR + UVA+UVB treatments, especially at $24^{\circ} \mathrm{C}$. It is noteworthy that the effect of the PAR + UVA+UVB treatment is the response to UVA and UVB radiation. Inferring only the UVB effect on PSII (\% reduction in PAR + UVA+UVB minus \% reduction in PAR + UVA), we noted that the percentage of inhibition of PSII caused by UVB was $30 \%$ in MIRF and $23 \%$ in CYRF at $24^{\circ} \mathrm{C}$. Surprisingly, at $28^{\circ} \mathrm{C}$, the percentage of UVB inhibition increased to $48 \%$ and $38 \%$ in MYRF and CYRF, respectively. The adverse effect of UVA $(315-400 \mathrm{~nm})$ on primary producers can be attributed, mostly, to pigment degradation (69-71), and damage in the PSII complex, especially to the D1 protein (72). The attenuation of the PAR + UVA+UVB effect on PSII efficiency at $28^{\circ} \mathrm{C}$ found in our results indicates that the increase of the temperature primarily reduced the photoinhibition by UVA. Since the primary target of UVA radiation is the D1 protein, and de novo synthesis of the D1 protein is temperature-dependent (44), we assumed that the increase of the temperature contributed to enhanced repair of UVA damage.

The accumulative effect of UVR exposure on PSII efficiency was assessed via the measurements that were recorded daily just before the exposure, allowing for an approximately $20 \mathrm{~h}$ recovery (Fig. 3). Damage of PSII by UVR could be repaired in a strain of $M$. aeruginosa when the damaged cells were irradiated with PAR (29). Damage and repair rates may differ considerably between species (73). The latter study found a stronger effect of PAR + UVA+UVB on PSII efficiency than when the species were exposed to PAR + UVA; the five cyanobacteria species tested were most sensitive to UVR that caused reaction center damage (73). The repair rate in $M$. aeruginosa in that study was $90 \%$ of the damage rate, which was higher than the 5 to $44 \%$ in the other cyanobacteria (73). Inasmuch as photodamage is inevitable, a rapid repair of damaged PSII is essential to minimize costs (74). In the PSII repair cycle, degradation and de novo synthesis of the D1 protein play a crucial role (75). Increasing temperatures could result in a fast turn-over and repair of D1 protein, leading to a better photosynthetic response (3). Moreover, elevated temperatures promoted a faster recovery in two strains of Anabaena circinalis after exposure to low UVB intensity $\left(0.8 \mathrm{~W} \mathrm{~m}^{-2}\right)(27)$. At $24^{\circ} \mathrm{C}$, MIRF experienced a significant negative cumulative inhibition of PSII efficiency that was strongly reduced at $28^{\circ} \mathrm{C}$. In CYRF, a slight negative cumulative effect was observed at $24^{\circ} \mathrm{C}$, which disappeared at $28^{\circ} \mathrm{C}$. These findings indicate that $\mathrm{CYRF}$ may present more efficient repair mechanisms to ameliorate the photodamage caused by UVR. Species-specific effects of UVR have been documented in the literature $(28,43,26)$ and the classification of the species as UV-tolerant or sensitive based on their photosynthetic response might be related to an efficient PSII repair cycle that includes more active expression of $p s b \mathrm{~A}$ genes that encode the D1 protein $(76,77)$, and the accelerated de novo synthesis of the D1 protein (77).

Rapid light curves (RLCs) can reveal the actual state of photosynthesis capacity and have been used as an important tool in the investigation of ecophysiolocal responses to environmental changes in cyanobacteria and microalgae. The RLCs showed a significant decline in alpha, $\mathrm{rETR}_{\max }$ and $\mathrm{E}_{\mathrm{k}}$ values in the treatments with UVR addition, most pronounced in the PAR + UVA+UVB treatment for both strains at both temperatures. Our results revealed that the UVB radiation can cause a reduction of the efficiency of light capture due to the inactivation of PSII (alpha) (57), a degradation of the photosynthetic apparatus that resulted in a reduction in electron transport rate $\left(\mathrm{rETR}_{\max }\right)$, and a diminishing adaptability of the cell to the light environment $\left(\mathrm{E}_{\mathrm{k}}\right)$.

A decrease of alpha and $\mathrm{rETR}_{\max }$ values due to UVB exposure has been reported in green algae $(78,79)$, and diatoms $(80)$. In cyanobacteria, no effect was observed in alpha and $\mathrm{E}_{\mathrm{k}}$; 
however, a significant reduction was observed in the rETR during a 6-day exposure period of $M$. aeruginosa to $1.05 \mathrm{~W} \mathrm{~m}^{-2}$ of UVB (65). Zhang et al (2013) $(81,82)$ observed a distinguished sensibility in two $M$. aeruginosa strains when exposed to UVB intensities of 0.285 and $0.372 \mathrm{~W} \mathrm{~m}^{-2}$. In the present study, at $24^{\circ} \mathrm{C}$, it was not possible to estimate the RLC parameters for CYRF due to PSII efficiencies of zero after exposure, which indicates a complete impairment of the energy capture and transfer in this strain. At $28^{\circ} \mathrm{C}$, however, the negative effect on photosynthesis parameters was ameliorated, especially for CYRF. A similar observation was made by Wong et al. (2015) (78), who noted less inhibition of alpha and $\mathrm{rETR}_{\max }$ in a tropical Chlorella strain exposed to UVR when the temperature was increased to $30^{\circ} \mathrm{C}$ as a result of enhanced repair at higher temperature.

A higher efficiency of PSII leads to a better photosynthetic performance which in turn, would mean a greater utilization of solar radiation for biomass production. Growth inhibition by UVR would be related to the efficiency of the recovery mechanisms of PSII after radiation exposure. In general, increased temperature would raise metabolic rates that, consequently, would shift the balance between inhibition and recovery of photosynthetic performance resulting in cell recovery or energy dissipation. In our study, CYRF showed slightly lower growth rates in the PAR + UVA+UVB treatment at $28^{\circ} \mathrm{C}$, whilst there was no apparent lasting negative effect on PSII efficiency. Costs of repair and of photosynthesis income loss due to the short-term damage and during repair (74) is the most probable explanation. In addition, UVB radiation may also cause other direct detrimental effects, such as structural damage in DNA (83). Growth rate reduction could be a consequence of compromised essential cell functions and additional metabolic costs for the repair mechanisms to lessen cellular damages induced by UVR on DNA (83).

Till date, a limited amount of studies have reported on the combined effects of increased temperature and UVR on cyanobacteria $(43,27,44)$. These studies, however, were carried out with species that were isolated from temperate regions. In this study, two tropical species were used. Tropical phytoplankton communities are naturally exposed to high intensities of UVA and UVB radiation (84), and, thus, tropical strains could be more tolerant to UVR. In the present work, we demonstrated that tropical strains, originally from the same system, expressed different responses to UVR stress in addition to temperature increase. The hypothesis that CYRF would be more sensitive to UVR when compared to MIRF had to be refuted, despite the fact that MIRF flourishes in the summer months in the reservoir $(85,48)$. It should be stressed again that $M$. aeruginosa MIRF in this study grew as single cells, while it is well established that the formation of colonies is an efficient way to protect against UV radiation (86). Likewise, although single cells are frequently observed in the natural population in the reservoir from where the strain was isolated, periods of high biomass of $M$. aeruginosa and the formation of large colonies coincided with periods of high light intensity (48). This indicates that this strategy (formation of large colonies) can be of paramount importance to protect $M$. aeruginosa against photoinhibition caused by high intensities of PAR and UVR.

In summary, we demonstrated that the negative effect of UVR is species-specific. Although the increase in temperature counteracted the detrimental effect caused by UVR exposure in both strains, the $R$. raciborskii strain seemed to benefit more with an increase in temperature, because it showed little or no cumulative damage, especially in the treatment with UVB addition. Hence, the increasing global temperature due to anthropogenic activities combined with UVR stress could influence species competition, and thus, the community composition in aquatic ecosystems.

Acknowledgements-This study was conducted under the flag of the CAPES (Brazil)/NUFFIC (The Netherlands) project 045/12 and was part of NPN PhD Thesis in Post-graduation in Ecology Program of Federal University of Rio de Janeiro with scholarship provided by CAPES and partially supported by WIMEK research fellowship grant - Wageningen University \& Research Center. MMM and VLMH were partially supported by the National Council for Scientific and Technological Development, Brazil, CNPq (303572/2017-5 and 304284/2017-3, respectively).

\section{SUPPORTING INFORMATION}

Additional supporting information may be found online in the Supporting Information section at the end of the article:

Figure S1. Chlorophyll- $a$ concentration $\left(\mu \mathrm{g} \mathrm{L}^{-1}\right)$ of Raphidiopsis raciborskii (CYRF) and Microcystis aeruginosa (MIRF) per day at $24^{\circ} \mathrm{C}$ and $28^{\circ} \mathrm{C}$. Symbols indicate mean values of the different light treatments: PAR + UVA+UVB, PAR + UVA and PAR. Error bars indicate one standard deviation $(n=3)$.

Figure S2. Biovolume $\left(\mu \mathrm{m}^{3} \mathrm{~mL}^{-1}\right)$ of Raphidiopsis raciborskii (CYRF) and Microcystis aeruginosa (MIRF) per day at $24^{\circ} \mathrm{C}$ and $28^{\circ} \mathrm{C}$. Symbols indicate mean values of the different light treatments: PAR + UVA+UVB, PAR + UVA and PAR. Error bars indicate one standard deviation $(n=3)$.

Figure S3. Number of particles per $\mathrm{mL}$ of Raphidiopsis raciborskii (CYRF) and Microcystis aeruginosa (MIRF) per day at $24^{\circ} \mathrm{C}$ and $28^{\circ} \mathrm{C}$. Symbols indicate mean values of the different light treatments: PAR + UVA+UVB, PAR + UVA and PAR. Error bars indicate one standard deviation $(n=3)$.

Figure S4. Growth rates of Raphidiopsis raciborskii (CYRF) and Microcystis aeruginosa (MIRF) based on the number of particles at $24^{\circ} \mathrm{C}$ and $28^{\circ} \mathrm{C}$. Error bars indicate one standard deviation $(n=3)$.

Figure S5. Mean particle volume $\left(\mu^{3}\right)$ of Raphidiopsis raciborskii (CYRF) and Microcystis aeruginosa (MIRF) per day at $24^{\circ} \mathrm{C}$ and $28^{\circ} \mathrm{C}$. Symbols indicate mean values of the different radiation treatments: PAR + UVA+UVB, PAR + UVA and PAR. Error bars indicate one standard deviation $(n=3)$.

\section{REFERENCES}

1. Caldwell, M. M., L. O. Björn, J. F. Bornman, S. D. Flint, G. Kulandaivelu, A. H. Teramura and M. Tevini (1998) Effects of increased solar ultraviolet radiation on terrestrial ecosystems. J. Photochem. Photobiol., B 46, 40-52.

2. Hader, D. P. (2001) Effects of solar UV-B radiation on aquatic ecosystems. Life Sciences: Planetary Protection; Ozone and UVB. Radiation Effects. 26, 2029-2040.

3. Bouchard, J. N., D. A. Campbell and S. Roy (2005) Effects of UV$\mathrm{B}$ radiation on the D1 protein repair cycle of natural phytoplankton communities from three latitudes (Canada, Brazil, and Argentina). $J$. Phycol. 41, 273-286.

4. Gao, K., H. Yu and M. T. Brown (2007) Solar PAR and UV radiation affects the physiology and morphology of the cyanobacterium Anabaena sp PCC 7120. J. Photochem. Photobiol. B 89, $117-124$. 
5. Rastogi, R. P., S. P. Singh, D.-P. Häder and R. P. Sinha (2011) Ultraviolet-B-induced DNA damage and photorepair in the cyanobacterium Anabaena variabilis PCC 7937. Environ. Exp. Bot. 74, 280-288.

6. Sinha, R. P. and D. P. Hader (2008) UV protectants in cyanobacteria. Plant Sci. 174, 278-289.

7. Harrison, J. W., G. M. Silsbe and R. E. Smith (2015) Photophysiology and its response to visible and ultraviolet radiation in freshwater phytoplankton from contrasting light regimes. J. Plankton Res. 37, 472-488.

8. Beecraft, L., S. B. Watson and R. E. Smith (2017) Multi-wavelength Pulse Amplitude Modulated fluorometry (Phyto-PAM) reveals differential effects of ultraviolet radiation on the photosynthetic physiology of phytoplankton pigment groups. Freshw. Biol. 62, 72-86.

9. Gao, K., Y. Wu, G. Li, H. Wu, V. E. Villafane and E. W. Helbling (2007) Solar UV radiation drives CO2 fixation in marine phytoplankton: a double-edged sword. Plant Physiol. 144, 54-59.

10. Buma, A. G., P. Boelen and W. H. Jeffrey. (2003) UVR-induced DNA damage in aquatic organisms. UV effects in aquatic organisms and ecosystems, $(\mathbf{1}, 291-327)$. Comprehensive series in photochemical \& photobiological sciences. Cambridge: The Royal Society of Chemistry.

11. Hargreaves, B., S. Girdner, M. Buktenica, R. Collier, E. Urbach and G. Larson (2007) Ultraviolet radiation and bio-optics in Crater Lake, Oregon. Long-term Limnological Research and Monitoring at Crater Lake, pp. 107-140.Springer, Oregon.

12. Crutzen, P. J. (1992) Ultraviolet on the increase. Nature 356, 104-105.

13. Montzka, S. A., G. S. Dutton, P. Yu, E. Ray, R. W. Portmann, J. S. Daniel, L. Kuijpers, B. D. Hall, D. Mondeel, C. Siso, J. D. Nance, M. Rigby, A. J. Manning, L. Hu, F. Moore, B. R. Miller and J. W. Elkins (2018) An unexpected and persistent increase in global emissions of ozone-depleting CFC-11. Nature 557, 413-417.

14. pDavis, M. E., F. Bernard, M. R. McGillen, E. L. Fleming and J. B. Burkholder (2016) UV and infrared absorption spectra, atmospheric lifetimes, and ozone depletion and global warming potentials for $\mathrm{CCl} 2 \mathrm{FCCl} 2 \mathrm{~F}$ (CFC-112), CCl3CClF2 (CFC-112a), CCl3CF3 (CFC-113a), and CCl2FCF3 (CFC-114a). Atmos. Chem. Phys. 16, 8043-8052.

15. Flato, G., J. Marotzke, B. Abiodun, P. Braconnot, S. C. Chou, W. Collins, P. Cox, F. Driouech, S. Emori and V. Eyring (2013) Evaluation of climate models. Cambridge University Press, Cambridge.

16. IPCC (2018) Global warming of 1.5 C. In An IPCC Special Report on the Impacts of Global Warming of $1.5^{\circ} \mathrm{C}$ Above Pre-industrial Levels and Related Global Greenhouse Gas Emission Pathways, in the Context of Strengthening the Global Response to the Threat of Climate Change, Sustainable Development, and Efforts to Eradicate Poverty. (Edited by V. Masson-Delmotte, P. Zhai, H.-O. Pörtner, D. Roberts, J. Skea, P. R. Shukla, A. Pirani, W. Moufouma-Okia, C. Péan and R. Pidcock), In Press.

17. Hader, D. P., E. W. Helbling, C. E. Williamson and R. C. Worrest (2011) Effects of UV radiation on aquatic ecosystems and interactions with climate change. Photochem. Photobiol. Sci. 10, 242-260.

18. Wrona, F. J., T. D. Prowse, J. D. Reist, J. E. Hobbie, L. M. Levesque and W. F. Vincent (2006) Climate change effects on aquatic biota, ecosystem structure and function. Ambio 35, 359-369.

19. Paerl, H. W. and J. Huisman (2009) Climate change: A catalyst for global expansion of harmful cyanobacterial blooms. Environ. Microbiol. Rep. 1, 27-37.

20. O'Neil, J., T. Davis, M. Burford and C. Gobler (2012) The rise of harmful cyanobacteria blooms: the potential roles of eutrophication and climate change. Harmful Algae 14, 313-334.

21. Yvon-Durocher, G., J. I. Jones, M. Trimmer, G. Woodward and J. M. Montoya (2010) Warming alters the metabolic balance of ecosystems. Philos. Trans. R Soc. Lond. B Biol. Sci. 365, 2117-2126.

22. Reynolds, C. S. (2006) The Ecology of Phytoplankton. Cambridge University Press, Cambridge.

23. Jankowski, T., D. M. Livingstone, H. Bührer, R. Forster and P. Niederhauser (2006) Consequences of the 2003 European heat wave for lake temperature profiles, thermal stability, and hypolimnetic oxygen depletion: Implications for a warmer world. J. Limnol. Oceanogr. 51, 815-819.

24. Butcher, J. B., D. Nover, T. E. Johnson and C. M. Clark (2015) Sensitivity of lake thermal and mixing dynamics to climate change. Clim. Change. 129, 295-305.
25. Castenholz, R. W., F. Garcia-Pichel and B. A. Whitton (2012) Cyanobacterial responses to UV radiation. Ecology of Cyanobacteria II, pp. 481-499.Springer, Dordrecht, Netherlands.

26. Islam, M. A. and J. Beardall (2020) Effects of temperature on the UV-B sensitivity of toxic cyanobacteria Microcystis aeruginosa CS558 and Anabaena circinalis CS537. Photochem. Photobiol. 96, 936-940.

27. Islam, M. A., J. Beardall and P. Cook (2019) Intra-strain variability in the effects of temperature on UV-B sensitivity of cyanobacteria. Photochem. Photobiol. 95, 306-314.

28. Beamud, G., P. Vico, S. Haakonsson, G. M. de la Escalera, C. Piccini, B. M. Brena, M. Pirez and S. Bonilla (2016) Influence of UV-B radiation on the fitness and toxin expression of the cyanobacterium Cylindrospermopsis raciborskii. Hydrobiologia $\mathbf{7 6 3}$, $161-172$.

29. Jiang, H. and B. Qiu (2011) Inhibition of photosynthesis by UV-B exposure and its repair in the bloom-forming cyanobacterium Microcystis aeruginosa. J. Appl. Phycol. 23, 691-696.

30. Zeeshan, M. and S. M. Prasad (2009) Differential response of growth, photosynthesis, antioxidant enzymes and lipid peroxidation to UV-B radiation in three cyanobacteria. South African J. Bot. 75, 466-474.

31. Wu, H., K. Gao, V. E. Villafañe, T. Watanabe and E. W. Helbling (2005) Effects of solar UV radiation on morphology and photosynthesis of filamentous cyanobacterium Arthrospira platensis. Appl. Environ. Microbiol. 71, 5004-5013.

32. Bebout, B. M. and F. Garcia-Pichel (1995) UV B-induced vertical migrations of cyanobacteria in a microbial mat. Appl. Environ. Microbiol. 61, 4215-4222.

33. Sinha, R. P. and D.-P. Häder (2002) UV-induced DNA damage and repair: a review. Photochem. Photobiol. Sci. 1, 225-236.

34. Paerl, H. W. and T. G. Otten (2013) Harmful cyanobacterial blooms: causes, consequences, and controls. Microb. Ecol. 65, 995-1010.

35. Meriluoto, J., L. Spoof and G. A. Codd (2017) Handbook of cyanobacterial monitoring and cyanotoxin analysis. John Wiley \& Sons, Chichester, West Sussex.

36. Briand, J. F., C. Robillot, C. Quiblier-Lloberas, J. F. Humbert, A. Coute and C. Bernard (2002) Environmental context of Cylindrospermopsis raciborskii (Cyanobacteria) blooms in a shallow pond in France. Water Res. 36, 3183-3192.

37. Padisák, J. (1997) Cylindrospermopsis raciborskii (Woloszynska) Seenaya et Subba Raju, an expanding, highly adaptative cyanobacterium: worldwide distribution and review of its ecology. Archiv für Hydrobiologie 107, 563-593.

38. Carneiro, R. L., A. P. R. d. Silva and V. F. d. Magalhães (2013) Use of the cell quota and chlorophyll content for normalization of cylindropermopsin produced by two Cylindrospermopsis raciborskii strains grown under different light intensities. Ecotoxicol. Environ. Contaminat. 8, 93-100.

39. Mesquita, M. C., M. Lürling, F. Dorr, E. Pinto and M. M. Marinho (2019) Combined effect of light and temperature on the production of saxitoxins in Cylindrospermopsis raciborskii strains. Toxins 11, 38.

40. Robarts, R. D. and T. Zohary (1992) The influence of temperature and light on the upper limit of Microcystis aeruginosa production in a hypertrophic reservoir. J. Plankton Res. 14, 235-247.

41. Robarts, R. D. and T. Zohary (1987) Temperature effects on photosynthetic capacity, respiration, and growth rates of bloom-forming cyanobacteria. NZ J. Mar. Freshwat. Res. 21, 391-399.

42. Torres, C. d. A., M. Lürling and M. M. Marinho (2016) Assessment of the effects of light availability on growth and competition between strains of Planktothrix agardhii and Microcystis aeruginosa. Microb. Ecol. 71, 802-813.

43. Giordanino, M. V. F., S. M. Strauch, V. E. Villafañe and E. W. Helbling (2011) Influence of temperature and UVR on photosynthesis and morphology of four species of cyanobacteria. J. Photochem. Photobiol., B 103, 68-77.

44. Roos, J. C. and W. F. Vincent (1998) Temperature dependence of UV radiation effects on Antarctic cyanobacteria. J. Phycol. 34, $118-125$.

45. Gao, K., P. Li, T. Watanabe and E. Walter Helbling (2008) Combined effects of ultraviolet radiation and temperature on morphology, photosynthesis, and DNA of Arthrospira (Spirulina) Platensis (Cyanophyta). J. Phycol. 44, 777-786. 
46. Rangel, L. M., K. A. Ger, L. H. Silva, M. C. S. Soares, E. J. Faassen and M. Lürling (2016) Toxicity overrides morphology on Cylindrospermopsis raciborskii grazing resistance to the calanoid copepod Eudiaptomus gracilis. Microb. Ecol. 71, 835-844.

47. Mello, M. M. E., M. C. S. Soares, F. Roland and M. Lürling (2012) Growth inhibition and colony formation in the cyanobacterium Microcystis aeruginosa induced by the cyanobacterium Cylindrospermopsis raciborskii. J. Plankton Res. 34, 987-994.

48. Soares, M., M. de A Rocha, M. Marinho, S. Azevedo, C. Branco and V. Huszar (2009) Changes in species composition during annual cyanobacterial dominance in a tropical reservoir: physical factors, nutrients and grazing effects. Aquat. Microb. Ecol. 57, 137-149.

49. Lurling, M. and W. Beekman (2006) Palmelloids formation in Chlamydomonas reinhardtii : defence against rotifer predators? Ann. Limnol. - Int. J. Lim. 42, 65-72.

50. Noyma, N. P., T. P. Silva, H. Chiarini-Garcia, A. M. Amado, F. Roland and R. C. Melo (2015) Potential effects of UV radiation on photosynthetic structures of the bloom-forming cyanobacterium Cylindrospermopsis raciborskii CYRF-01. Front. Microbiol. 6, 1202.

51. de Lange, H. J. and P. L. Van Reeuwijk (2003) Negative effects of UVB-irradiated phytoplankton on life history traits and fitness of Daphnia magna. Freshw. Biol. 48, 678-686.

52. Soares, M. C. S., M. M. Marinho, S. M. O. F. Azevedo, C. W. C. Branco and V. L. M. Huszar (2012) Eutrophication and retention time affecting spatial heterogeneity in a tropical reservoir. Limnol. Ecol. Managem. Inland Waters 42, 197-203.

53. Marengo, J. A., T. Ambrizzi, R. P. Da Rocha, L. M. Alves, S. V. Cuadra, M. C. Valverde, R. R. Torres, D. C. Santos and S. E. Ferraz (2010) Future change of climate in South America in the late twenty-first century: intercomparison of scenarios from three regional climate models. Clim. Dyn. 35, 1073-1097.

54. Döhler, G. and M. Lohmann (1995) Impact of UV radiation of different wavebands on the pigmentation of the haptophycean Pavlova. J. Photochem. Photobiol., B 27, 265-270.

55. Marinho, M. M. and S. M. F. O. Azevedo (2007) Influence of N/P ratio on competitive abilities for nitrogen and phosphorus by Microcystis aeruginosa and Aulacoseira distans. Aquat. Ecol. 41, 525-533.

56. Platt, T., C. Gallegos and W. G. Harrison (1980) Photoinhibition of photosynthesis in natural assemblages of marine phytoplankton. $J$. Mar. Res. 38, 687-701.

57. Ralph, P. J. and R. Gademann (2005) Rapid light curves: a powerful tool to assess photosynthetic activity. Aquat. Bot. 82, 222-237.

58. Harrison, W. and T. Platt (1986) Photosynthesis-irradiance relationships in polar and temperate phytoplankton populations. Polar Biol. 5, 153-164.

59. Schreiber, U. (2004) Pulse-amplitude-modulation (PAM) fluorometry and saturation pulse method: an overview. Chlorophyll-a fluorescence, pp. 279-319.Springer, Dordrecht.

60. Henley, W. J. (1993) Measurement and interpretation of photosynthetic light-response curves in algae in the context of photoinhibition and diel changes. J. Phycol. 29, 729-739.

61. Lürling, M., F. van Oosterhout, L. de Senerpont Domis and M. M. Marinho (2018) Response of natural cyanobacteria and algae assemblages to a nutrient pulse and elevated temperature. Front. Microbiol. 9, 1851.

62. Elser, J. J., M. E. Bracken, E. E. Cleland, D. S. Gruner, W. S. Harpole, H. Hillebrand, J. T. Ngai, E. W. Seabloom, J. B. Shurin and J. E. Smith (2007) Global analysis of nitrogen and phosphorus limitation of primary producers in freshwater, marine and terrestrial ecosystems. Ecol. Lett. 10, 1135-1142.

63. Silsbe, G. and S. Malkin (2015) Phytotools: phytoplankton production tools. An R package available on CRAN: https://cran.r-project. org/web/packages/phytotools/index.html.

64. Sinha, R. P. and D.-P. Hader (1998) Effects of ultraviolet-B radiation in three rice field cyanobacteria. J. Plant Physiol. 153, 763-769.

65. Jiang, H. and B. Qiu (2005) Photosynthetic adaptation of a bloomforming cyanobacterium Microcystis aeruginosa (Cyanophyceae) to prolonged UV-B exposure. J. Phycol. 41, 983-992.

66. Van Donk, E., B. Faafeng, H. De Lange and D. Hessen (2001) Differential sensitivity to natural ultraviolet radiation among phytoplankton species in Arctic lakes (Spitsbergen, Norway). Plant Ecol. 154, 247-259.
67. Qin, H., S. Li and D. Li (2015) Differential responses of different phenotypes of Microcystis (Cyanophyceae) to UV-B radiation. Phycologia 54, 118-129.

68. Hedges, L. V., J. Gurevitch and P. S. Curtis (1999) The meta-analysis of response ratios in experimental ecology. Ecology 80, 1150-1156.

69. Döhler, G. and T. Buchmann (1995) Effects of UV-A and UV-B irradiance on pigments and $15 \mathrm{~N}$-ammonium assimilation of the haptophycean Pavlova. J. Plant Physiol. 146, 29-34.

70. Kim, D.-S. and Y. Watanabe (1994) Inhibition of growth and photosynthesis of freshwater phytoplankton by ultraviolet A (UVA) radiation and subsequent recovery from stress. J. Plankton Res. 16, 1645-1654.

71. Palffy, K. and L. Voros (2006) Effects of UV-A radiation on Desmodesmus armatus: Changes in growth rate, pigment content and morphological appearance. Int. Rev. Hydrobiol. 91, 451-465.

72. Turcsányi, E. and I. Vass (2000) Inhibition of photosynthetic electron transport by UV-A radiation targets the photosystem II complexII. Photochem. Photobiol. 72, 513-520.

73. Beecraft, L., S. B. Watson and R. E. Smith (2019) Innate resistance of PSII efficiency to sunlight stress is not an advantage for cyanobacteria compared to eukaryotic phytoplankton. Aquat. Ecol. 53, 347-364.

74. Raven, J. A. (2011) The cost of photoinhibition. Physiol. Plant. 142, 87-104.

75. Wu, H., L. Abasova, O. Cheregi, Z. Deák, K. Gao and I. Vass (2011) D1 protein turnover is involved in protection of Photosystem II against UV-B induced damage in the cyanobacterium Arthrospira (Spirulina) platensis. J. Photochem. Photobiol., B 104, 320-325.

76. Máté, Z., L. Sass, M. Szekeres, I. Vass and F. Nagy (1998) UV-Binduced differential transcription of psbAGenes encoding the D1 protein of photosystem II in the Cyanobacterium Synechocystis 6803. J. Biol. Chem. 273, 17439-17444.

77. Campbell, D., M.-J. Eriksson, G. Öquist, P. Gustafsson and A. K. Clarke (1998) The cyanobacterium Synechococcus resists UV-B by exchanging photosystem II reaction-center D1 proteins. Proc. Nat Acad. Sci. 95, 364-369.

78. Wong, C.-Y., M.-L. Teoh, S.-M. Phang, P.-E. Lim and J. Beardall (2015) Interactive effects of temperature and UV radiation on photosynthesis of Chlorella strains from polar, temperate and tropical environments: differential impacts on damage and repair. PLoS One 10, e0139469.

79. Cai, W., X. Gao, J. Hu, L. Chen, X. Li, Y. Liu and G. Wang (2016) UV-B radiation inhibits the photosynthetic electron transport chain in Chlamydomonas reinhardtii. Pak. J. Bot. 48, 2587-2593.

80. Shi, K., J. Yu, C. Liu, Z. Xu and X. Tang (2017) Impacts of enhanced UVB radiation on photosynthetic characteristics of the marine diatom Phaeodactylum tricornutum (Bacillariophyceae, Heterokontophyta). J. Appl. Phycol. 29, 1287-1296.

81. Zhang, Y., H.-B. Jiang and B.-S. Qiu (2013) Effects of UVB Radiation on competition between the bloom-forming cyanobacterium Microcystis aeruginosa and the Chlorophyceae Chlamydomonas microsphaera. J. Phycol. 49, 318-328.

82. Zhang, Y., H. B. Jiang and B. S. Qiu (2013) Effects of UVB radiation on competition between the bloom-forming cyanobacterium Microcystis aeruginosa and the Chlorophyceae Chlamydomonas microsphaera. J. Phycol. 49, 318-328.

83. Buma, A., A. Engelen and W. Gieskes (1997) Wavelength-dependent induction of thymine dimers and growth rate reduction in the marine diatom Cyclotella sp. exposed to ultraviolet radiation. Mar. Ecol. Prog. Ser. 153, 91-97.

84. Corrêa, M. d. P. (2015) Solar ultraviolet radiation: Properties, characteristics and amounts observed in Brazil and South America. An. Bras. Dermatol. 90, 297-313.

85. Guedes, I. A., D. M. da Costa Leite, L. A. Manhães, P. M. Bisch, S. M. F. O. Azevedo and A. B. F.o Pacheco (2014) Fluctuations in microcystin concentrations, potentially toxic Microcystis and genotype diversity in a cyanobacterial community from a tropical reservoir. Harmful Algae 39, 303-309.

86. Sommaruga, R., Y. Chen and Z. Liu (2009) Multiple strategies of bloom-forming Microcystis to minimize damage by solar ultraviolet radiation in surface waters. Microb. Ecol. 57, 667-674. 